\title{
PENGEMBANGAN LEMBAR KERJA PESERTA DIDIK (LKPD) BERBASIS PROBLEM BASED LEARNING DALAM PEMBELAJARAN MATEMATIKA KELAS IV SEKOLAH DASAR
}

\author{
Septiana Andeswari ${ }^{1 *}$, Dudung Amir Sholeh ${ }^{2}$, Linda Zakiyah ${ }^{3}$ \\ 1,2,3 Universitas Negeri Jakarta, Jakarta, Indonesia \\ *Corresponding Author: $\otimes$ septianaandeswari@yahoo.com
}

\begin{tabular}{|c|}
\hline Info Artikel \\
\hline $\begin{array}{l}\text { Sejarah Artikel: } \\
\text { Diterima: 05/11/2021 } \\
\text { Direvisi : 18/11/2021 } \\
\text { Disetujui: 28/11/2021 }\end{array}$ \\
\hline $\begin{array}{lr}\text { Keywords: } & \\
\text { Student } & \text { worksheets, } \\
\text { Problem } & \text { Based } \\
\text { Learning, Geometry, } & \text { Teaching materials }\end{array}$ \\
\hline $\begin{array}{l}\text { Kata Kunci: } \\
\text { LKPD, Problem Base } \\
\text { Learning, Geometri } \\
\text { bahan ajar }\end{array}$ \\
\hline
\end{tabular}

\begin{abstract}
This study was conducted to determine the development and feasibility of learning media student worksheets (LKPD) based on Problem Based Learning in learning mathematics for grade IV elementary schools. The research method used in this study is research and development (Research and Development) which uses four stages of the Borg and Gall research and development model, namely: 1) research and information collecting, 2) Planning, 3) develop preliminary form a product, 4) preliminary field testing 5) main product revision, 6) main field testing 7) operational product revision 8) operational field testing, 9) final product revision, 10) desimination. The result of this research and development is a problem based learning $L K P D$ product in the fourth grade elementary school mathematics learning. The feasibility level based on the results of the percentage assessment of material experts, learning media experts, and linguists respectively got $90.47 \%, 82.28 \%$, and $73.3 \%$ with the criteria of "very feasible". Furthermore, the response of students to the product when it was tested in the main field testing stage of the LKPD problem based product also did not require improvement and got a percentage of $95.17 \%$ with the criteria of "very good". Based on the results of interviews with fourth grade teachers, teachers are interested in using problem-based learning LKPD products in mathematics learning activities in the classroom. Based on this, it can be concluded that problem-based learning LKPD is appropriate to be used as one of the mathematics teaching materials in geometry learning.
\end{abstract}

Abstrak. Amanat undang-undang menggariskan bahwa empat kompetensi yang harus dikuasai guru meliputi kompetensi kompetensi kepribadian, pedagogik, kompetensi sosial dan kompetensi professional. Namun dalam pelaksanaanya masih banyak kendala yang dihadapi oleh guru. Penelitian ini dilakukan untuk mengetahui pengembangan dan kelayakan dari media pembelajaran lembar kerja peserta didik (LKPD) berbasis problem based learning dalam pembelajaran matematika kelas IV sekolah dasar. Metode penelitian yang digunakan dalam penelitian ini adalah penelitian dan pengembangan (Research and Development) yang menggunakan empat tahapan dari model penelitian dan pengembangan Borg and Gall, yaitu: 1) research and information collecting, 2) Planning ,3) develop preliminary form a product, 4) preliminary field testing 5) main product revision, 6) main field testing 7) operational product revision 8) Operational Field Testing, 9) Final Product Revision, 10) Desimination. Hasil dari penelitian dan pengembangan ini adalah produk LKPD berbasis problem based learning dalam pembelajaran matematika kelas IV sekolah dasar. Tingkat kelayakan berdasarkan hasil persentase penilaian ahli materi, ahli media pembelajaran, dan ahli bahasa masing-masing mendapatkan $90.47 \%, 82.28 \%$, dan $73.3 \%$ dengan kriteria "sangat layak". Selanjutnya, respon peserta didik terhadap produk saat diuji cobakan dalam tahap main field testing produk LKPD juga tidak memerlukan perbaikan serta mendapatkan presentase sebesar 95.17\% dengan kriteria "sangat baik". Berdasarkan hasi wawancara dengan guru kelas IV, guru tertarik untuk menggunakan produk LKPD berbasis problem based learning dalam kegiatan pembelajaran matematika didalam kelas. Berdasarkan hal tersebut, dapat disimpulkan bahwa LKPD berbasis problem based learning layak digunakan sebagai salah satu bahan ajar matematika pada pembelajaran geometri.

How to Cite: Andeswari, S., Sholeh, D.A., \& Zakiyah, L. (2022). PENGEMBANGAN LEMBAR KERJA PESERTA DIDIK (LKPD) BERBASIS PROBLEM BASED LEARNING DALAM PEMBELAJARAN MATEMATIKA KELAS IV SEKOLAH DASAR. Prima Magistra: Jurnal Ilmiah Kependidikan, 3(1), 48-61. https://doi.org/10.37478/jpm.v3i1.1313

\footnotetext{
Alamat korespondensi:

Jl. Taman Setia Budi I No.2, RW.2, Kuningan, Kecamatan Setiabudi, Kota Jakarta Selatan, Daerah Khusus Ibukota Jakarta 12910. septianaandeswari@yahoo.com
}

\author{
Penerbit: \\ Program Studi PGSD Universitas Flores. \\ (8) primagistrauniflor@gmail.com
}


Septiana Andeswari , Dudung Amir Sholeh, Linda Zakiyah

Pengembangan Lembar Kerja Peserta Didik (LKPD) Berbasis Problem Based Learning dalam Pembelajaran Matematika Kelas IV Sekolah Dasar

Prima Magistra: Jurnal Ilmiah Kependidikan Volume 3, Nomor 1, Januari 2022, hal 48-61

\section{PENDAHULUAN}

Matematika merupakan salah satu mata pelajaran yang diajarkan pada tingkat sekolah dasar. Oleh karena itu, pengusaan terhadap mata pelajaran matematika di sekolah dasar ini tidak dapat dikesampingkan karena hal ini akan berpengaruh pada jenjang pendidikan berikutnya. Pada tingkat sekolah dasar ini, pembelajaran matematika merupakan tantangan tersendiri yang tidak mudah dari waktu ke waktu sehingga penting untuk mengajarkan konsep dasar matematika di jenjang sekolah dasar dengan benar dan kuat (Suryadi, 2010; Lestari, 2015). Hitungan dasar matematika seperti penjumlahan, pengurangan, perkalian dan pembagian harus dapat benar-benar dikuasai oleh siswa sekolah dasar (Fathurohman \& Ulya, 2021; Fitrianti, 2021; Handayani, 2021).

Kenyataan yang terjadi selama ini, penguasaan matematika pada tingkat sekolah dasar masih tergolong rendah (Saputra et al., 2021; Perdana \& Suswandari, 2021). Hal ini terjadi karena ketidaksukaan peserta didik pada mata pelajaran matematika. Menurut Andrayani (2015), matematika merupakan mata pelajaran yang sulit, mata pelajaran yang paling tidak disukai bahkan dibenci oleh sebagian besar siswa sekolah dasar. Mereka mengeluhkan bawa mata pelajaran matematika merupakan pelajaran yang sulit dimengerti dan dibayangkan oleh mereka karena melibatkan angka-angka yang abstrak bagi mereka.

Hasil riset yang dilakukan oleh PISA pada tahun 2012 (OECD, 2014) menunjukkan bahwa peserta didik di Indonesia memiliki kinerja yang rendah dalam menyelesaikan permodelan matematika. Indonesia menempati urutan ke 64 dari 65 negara yang berpartisipasi dengan perolehan skor 375 . Lebih lanjut, $75.7 \%$ peserta didik di Indonesia hanya mampu menyelesaikan permodelan matematika sederhana dan hanya $0.1 \%$ peserta didik di Indonesia yang mampu menyelesaikan permodelan matematika yang membutuhkan keterampilan berpikir tingkat tinggi dan keterampilan pemecahan masalah.

Hasil riset PISA ini menjadi sebuah penanda bahwa proses kegiatan pembelajaran matematika di sekolah-sekolah saat ini belum berjalan sebagaimana mestinya. Kegiatan pembelajaran matematika yang selama ini berlangsung belum dapat memberikan dampak bagi siswa dalam kemampuan berfikirnya.

Selain permasalahan terhadap ketarampilan berfikir tingkat tinggi dan keterampilan pemecahan masalah, terdapat permasalahan lain yang juga dialami oleh peserta didik dalam proses pembelajaran matematika (Fauzi \& Arisetyawan, 2020). Permasalah yang dialami peserta didik dalam proses kegiatan pembelajaran matematika antara lain (1) Peserta didik cenderung pasif dan lebih banyak diam saat proses pembelajaran, (2) Tidak adanya motivasi belajar yang dimiliki peserta didik dan kebanyakan peserta didik belajar karena keterpaksaan, (3) Peserta didik tidak menyadari esensi dari suatu konsep yang dipelajarinya dan hanya mengandalkan hafalan, dan (4) Respon peserta didik sangat rendah saat kegiatan pembelajaran terutama kegiatan pembelajaran matematika.

Permasalah permasalah tersebut sedikit banyak dialami oleh peserta didik karena kurangnya persiapan dan pengetahuan guru dalam mengajarkan matematika. Fauzi \& Arisetyawan (2020) mengatakan bahwa dalam kegiatan pembelajaran matematika, guru cenderung hanya menyampaikan pembelajaran secara informatif saja, artinya peserta didik hanya memperoleh informasi dari guru sehinga derajat kemelekatannya juga dapat dikatakan rendah. Lebih lanjut guru masih belum memberikan kesempatan kepada peserta didik untuk dapat mengeksplorasi kemampuan berfikirnya. Kegiatan pembelajaran belum dimulai dengan menghadapkan peserta didik kepada suatu permodelan matematika yang memerlukan pemecahan masalah, sehingga pembelajaran belum berorientasi kepada melatih peserta didik untuk menganalisis, melakukan eksperimen, mengolah informasi, melakukan kegiatan kolaboratif, menyimpulkan dan mengkomunikasikan temuan yang diperolehnya selama proses kegiatan pembelajaran. Dapat disimpulkan bahwa kegiatan pembelajaran selama ini yang berlangsung disekolah-sekolah belum 
Septiana Andeswari , Dudung Amir Sholeh, Linda Zakiyah

Pengembangan Lembar Kerja Peserta Didik (LKPD) Berbasis Problem Based Learning dalam Pembelajaran Matematika Kelas IV Sekolah Dasar

Prima Magistra: Jurnal Ilmiah Kependidikan Volume 3, Nomor 1, Januari 2022, hal 48-61

mengggunakan model pembelajaran yang dapat membantu peserta didik untuk melatih kemampuan pemecahan masalahnya.

Menurut hasil penelitian yang dilakukan oleh Indarwati (2014) salah satu model pembelajaran yang dapat digunakan untuk mengatasi permasalahan diatas adalah dengan menggunakan model pembelajaran problem based learning. Berdasarkan penelitian yang telah dilakukan tersebut, dapat disimpulkan bahwa penerepan model pembelajaran problem based learning dapat meningkatkan kemampuan pemecahan masalah operasi hitung bilangan pecahan pada siswa kelas V SDN Mlowo Karangtalun 04 Kecamatan Pulokulon Kabupaten Grobogan.

Problem Based Learning sendiri adalah salah satu model pembelajaran yang melibatkan peserta didik untuk aktif berpartisipasi secara langsung (Rahmadani \& Taufina, 2020). Model pembelajaran problem based learning adalah model pembelajaran yang diawali dengan menyediakan suatu permasalahan yang autentik bagi peserta didik sehingga pembelajaran menitikberatkan kepada keterampilan pemecahan masalah yang dimiliki peserta didik. Selanjutnya, Suprihatiningrum (2017) mengungkapkan bahwa problem based learning (PBL) adalah suatu model pembelajaran dimana peserta didik dari awal pembelajaran dihadapkan pada suatu masalah yang menuntut peserta didik untuk aktif mencari informasi-informasi untuk memecahkan permasalahan tersebut. Melindawati (2016) menyatakan bahwa Problem based learning didasarkan kepada penyelidikan autentik yakni penyelidikan yang membutuhkan penyelesaian nyata dari permasalahan yang nyata. Problem based learning dirasa mampu untuk membantu peserta didik dalam kegiatan pembelajaran matematika. Dengan model ini, peserta didik akan dapat memahami materi matematika melalui penyajian permasalahan yang ada.

Penggunaan model problem based learning ini dirasa mampu membantu peserta didik untuk meningkatkan keterampilan pemecahan masalah karena penyajian dalam problem based learning merupakan materi yang berkaitan dalam dunia nyata. Hal ini juga disampaikan oleh Komalasari (2017) bahwa model problem based learning adalah pembelajaran dengan menjadikan permasalahan dalam kehidupan sehari-hari sebagai konteksnya untuk membantu peserta didik dalam pemecahan masalah dan cara berfikir kritis sehingga peserta didik dapat memeperoleh pengetahuan dan konsep yang esensial dalam materi pelajaran yang dipelajarinya. Penyajian permasalahan yang relevan dengan kehidupan sehari-hari ini mempermudah peserta didik dalam memperoleh pengetahuan dan pemahaman akan sebuah konteks.

Selain model pembelajaran, dibutuhkan juga bahan ajar yang baik dan menarik agar proses pembelajaran mampu dipahami oleh peserta didik. Bahan ajar yang digunakan oleh guru akan menentukan kualitas pembelajaran. Bahan ajar yang baik akan mengantarakan kepada hasil pembelajaran yang baik, begitu pula sebaliknya.

Bahan ajar mempunyai beragam bentuk yakni, bahan ajar cetak, audio, audio visual dan interaktif. Salah satu contoh bahan ajar yang berbentuk cetak adalah Lembar Kerja Peserta Didik (LKPD). LKPD adalah lembaran-lembaran kegiatan dan tugas yang harus dikerjakan peserta didik dalam proses pembelajarannya. LKPD digunakan untuk meminimalkan peran guru dalam kegiatan pembelajaran sehingga pembelajaran berfokus kepada membangun pengetahuan peserta didik. LKPD membantu peserta didik agar pembelajaran berfokus kepada peserta didik.

Lembar Kerja Peserta Didik (LKPD) adalah salah satu bahan ajar yang dapat memfasilitasi peserta didik. LKPD merupakan bahan ajar yang mewadahi peserta didik untuk aktif mengembangkan sendiri pengetahuannya dan menjadikan peserta didik pusat dari kegiatan pembelajaran. LKPD membantu peserta didik untuk menkonkretkan konsep matematika yang bersifat abstrak sesuai dengan tahapan perkembangan peserta didik.

Berdasarkan hasil penelitian yang dilakukan oleh Septian et al. (2019) di kelas V SD Negeri 3 Karangnanas didapati hasil 
Septiana Andeswari , Dudung Amir Sholeh, Linda Zakiyah

Pengembangan Lembar Kerja Peserta Didik (LKPD) Berbasis Problem Based Learning dalam Pembelajaran Matematika Kelas IV Sekolah Dasar

Prima Magistra: Jurnal Ilmiah Kependidikan Volume 3, Nomor 1, Januari 2022, hal 48-61

bahwa terdapat pengaruh penggunaan Lembar Kerja Peserta Didik (LKPD) matematika berbasis model Realistic Mathematics Education terhadap prestasi belajar peserta didik. Hasil rata-rata nilai posttest di kelas ekperimen sebesar 77,9 sedangkan di kelas kontrol sebesar 68,7. Respon peserta didik terhadap penggunaan lembar kerja peserta didik (LKPD) sebanyak 93\% dengan kriteria sangat setuju dengan penggunaan lembar kerja peserta didik (LKPD) dalam kegiatan pembelajaran matematika.

Sebagian besar LKPD yang beredar saat ini masih masih belum mampu membantu peserta didik dalam memahami materi (Caswita \& Bharata, 2019). LKPD masih hanya berupa kumpulan soal-soal yang kurang menarik sehingga tidak berefek terhadap berkembangnya kemampuan peserta didik. Selain itu, soal-soal yang terdapat LKPD masih kurang bervariatif, peserta didik hanya diminta untuk mengisi titik-titik yang kosong atau menyilangkan jawaban. LKPD tidak melihat proses peserta didik melainkan hasil yang didapatkan oleh peserta didik. LKPD seperti ini tidak memicu peserta didik untuk aktif dalam pengembangan pengetahuan dan kemampuan berfikir tingkat tingginya. LKPD hanya membantu peserta didik dalam kegiatan menghafal rumus- rumus matematika yang ada.

Berdasarkan hasil wawancara yang dilakukan peneliti dengan peserta didik kelas IV sekolah dasar di SDN Randusongo 1, mengungkapkan bahwa dalam proses kegiatan pembelajaran guru masih belum menggunakan LKPD. Dalam kegiatan pembelajaran guru hanya menggunakan soalsoal yang tersedia di buku pelajaran yang disediakan oleh sekolah. Peserta didik cenderung mengerjakan soal-soal yang diberikan oleh guru tanpa memahami esensi dari materi yang diberikan.

Selain itu, karena kondisi saat ini yang mengharuskan peserta didik untuk belajar dari rumah, guru tidak dapat mengontrol kegiatan pembelajaran peserta didik. Menurut hasil wawancara yang dilakukan dengan guru kelas IV SDN Randusongo 1, untuk pembelajaran matematika saat ini masih hanya bersumber satu arah dari guru saja. Karena keterbatasan kemapuan yang dimiliki guru, guru belum mampu untuk mengembangkan bahan ajar yang menarik yang dapat membantu belajar peserta didik. Dalam kegiatan pembelajaran jarak jauh ini, guru hanya memberikan video yang bersumber dari youtube untuk ditonton peserta didik dan mengerjakan soal latihan yang telah diberikan. Guru menyadari kelemahan dari kegiatan pembelajaran yang seperti ini, disamping pembelajaran tidak membantu peserta didik dalam melatih kemampuan pemecahan masalahnya, guru juga tidak dapat mengetahui apakah peserta didik sudah benar-benar memahami materi yang diberikan karena guru tidak mengetahui apakah tugas yang diberikan benar-benar dikerjakan sendiri oleh peserta didik.

Untuk mengatasi permasalah tersebut dibutuhkan suatu pengembangan bahan ajar yang inovatif yang dapat mengembangkan kemampuan peserta didik. Salah satu bahan ajar yang dapat dikembangkan yakni bahan ajar berupa Lembar Kerja Peserta Didik berbasis Problem Based Learning dalam Pembelajaran Matematika Siswa Kelas IV Sekolah Dasar.

\section{METODE PENELITIAN}

Ditinjau dari tujuannya untuk mengembangkan suatu produk yang sudah ada menjadi produk baru yang lebih inovatif, yakni berupa pengembangan Lembar Kerja Peserta Didik (LKPD) berbasis Problem Based Learning pada Pembelajaran Matematika Di Kelas IV SD maka penelitian ini dapat digolongkan kedalam penelitian dan pengembangan atau dalam bahasa inggris disebut Research and Development $(R \& D)$. Menurut (Hanafi, 2017) penelitian dan pengembangan atau $\mathrm{R} \& \mathrm{D}$ adalah suatu proses yang digunakan untuk menciptakan atau mengembangakan suatu produk dan menguji validitas dari produk tersebut. Berdasarkan pengertian tersebut dapat dipahami bahwa penelitian dan pengembangan bukan hanya menciptakan atau mengembangkan suatu produk saja melainkan produk yang diciptakan maupun dikembangkan harus dapat dipertanggung jawabkan dan benar teruji manfaatnya.

Dalam penelitian Research \& 
Septiana Andeswari , Dudung Amir Sholeh, Linda Zakiyah

Pengembangan Lembar Kerja Peserta Didik (LKPD) Berbasis Problem Based Learning dalam Pembelajaran Matematika Kelas IV Sekolah Dasar

Prima Magistra: Jurnal Ilmiah Kependidikan Volume 3, Nomor 1, Januari 2022, hal 48-61

Development ini peneliti membutuhkan model pengembangan yang dapat digunakan dalam mengembangkan suatu produk. Dari berbagai macam model pengembangan yang dapat digunakan, peneliti menggunakan model pengembangan yang dikemukakan oleh Borg and Gall dalam mengembangkan Lembar Kerja Peserta Didik berbasis Problem Based Learning pada Pembelajaran Matematika Siswa Kelas IV Sekolah Dasar.

Berikut ini merupakan langkah-langkah penelitian dan pengembangan yang dikemukakan oleh Borg and Gall dalam (Pradita \& Wangid, 2017).

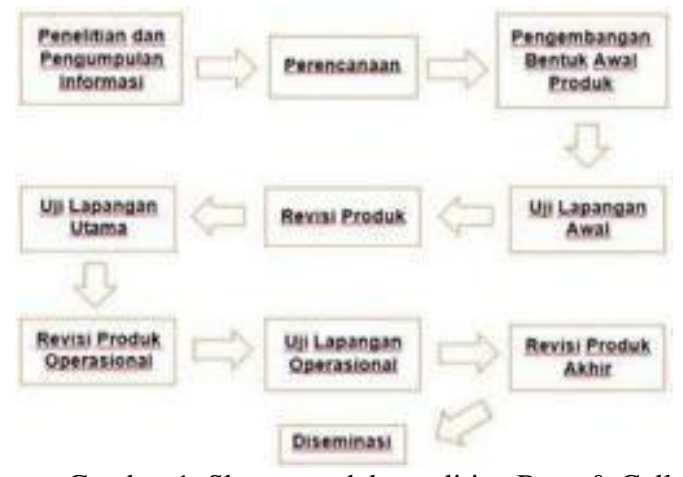

Gambar 1. Skema model penelitian Borg \& Gall

Teknik pengumpulan data yang digunakan dalam pengembangan lembar kerja peserta didik (LKPD) berbasis problem based learning pada pembelajaran matematika siswa kelas IV sekolah dasar ini menggunakan teknik wawancara dan angket. Wawancara dilakukan untuk menganalisa kebutuhan produk dan preliminary field testing. Sedangkan untuk pengumpulan data menggunakan angket, dilakukan dengan skala bertingkat saat penilaian oleh para ahli atau expert review (ahli materi, ahli bahasa dan ahli media), guru dan pada saat uji coba lapangan (main field testing dan operational field testing). Skala bertingkat digunakan untuk menilai kelayakan produk yang telah dikembangkan.

Peneliti menggunakan instrumen berupa angket yang berisi pertanyaanpertanyaan mengenai produk yang dikembangkan. Angket atau kuisioner digunakan untuk memperoleh data keefektifan penggunaan produk yang dikembangkan. Pertanyaan-pertanyaan yang terdapat dalam angket ini berangkat dari variabel yang akan dikembangkan dalam penelitian. Dalam penelitian ini, peneliti menggunakan instrumen angket dengan skala bertingkat atau rating scale.

Pada penelitian ini, teknik analisis data yang digunakan ialah skala nilai angka (Numeric Rating Scales). Menurut (Sukmadinata, 2011) skala nilai angka di gunakan untuk menghitung presepsi responden terhadap produk yang dikembangkan. Skala nilai angka ini memiliki interval 1 sampai 5 dengan pertimbangan 1 untuk "sangat kurang baik", 2 untuk "kurang baik", 3 untuk "cukup", 4 untuk "baik" dan 5 untuk "sangat baik". Setelah data terkumpul melalui kegiatan uji validasi, maka dapat dilakukan perhitungan untuk mengetahui kualitas Lembar Kerja Peserta Didik. Berikut adalah analisis data menurut Sukmadinata (2011) dengan menggunakan skala nilai angka.

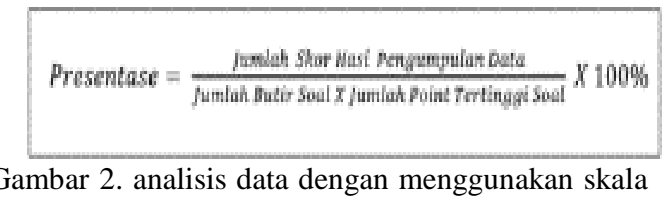
nilai angka

Setelah selesai melakukan perhitungan presentase uji validasi pengembangan produk, maka peneliti dapat menyimpulkan apakah Lembar Kerja Peserta Didik (LKPD) berbasis Problem Based Learning pada pembelajaran matematika ini memiliki nilai sangat kurang baik, kurang baik, cukup, baik, atau sangat baik digunakan dalam pembelajaran. Penarikan kesimpulan ini didasarkan pada penilaian LKPD menurut (Sukamadinata, 2011) seperti berikut:

Tabel 1. Rentang Presentase Penilaian LKPD

\begin{tabular}{ll} 
Tabel 1. Rentang Presentase Penilaian LKPD \\
\hline Penilaian & Presentase \\
\hline Sangat Kurang Baik & $0 \%-20 \%$ \\
Kurang Baik & $21 \%-40 \%$ \\
Cukup & $41 \%-60 \%$ \\
Baik & $61 \%-80 \%$ \\
Sangat Baik & $81 \%-100 \%$ \\
\hline
\end{tabular}

\section{HASIL DAN PEMBAHASAN}

Penelitian terdahulu menganai lembar kerja peserta didik dan problem based 
Septiana Andeswari , Dudung Amir Sholeh, Linda Zakiyah

Pengembangan Lembar Kerja Peserta Didik (LKPD) Berbasis Problem Based Learning dalam Pembelajaran Matematika Kelas IV Sekolah Dasar

Prima Magistra: Jurnal Ilmiah Kependidikan Volume 3, Nomor 1, Januari 2022, hal 48-61

learning menunjukkan adanya peningkatan pemahaman dalam pembelajaran matematika. Salah satunya adalah penelitian yang dilakukan oleh Mala et al. (2020) mengenai pengembangan LKPD berbasis HOTS. Dalam penelitian tersebut, pengembangan LKPD berbasis HOTS memperoleh hasil 85,6\% dengan kategori "sangat layak" sehingga dapat dinyatakan "Valid" oleh ahli materi dan ahli media. Kemudian, dari respon guru mendapatkan hasil $100 \%$ dengan kategori "sangat baik" dan hasil dari respon peserta didik memperoleh 96,03\% dengan kategori "sangat baik". Untuk aspek kemampuan berfikir tingkat tinggi dapat dilihat dari hasil tes pemahaman peserta didik yang mendapatkan nilai rata-rata kelas 91,25 dengan kategori "sangat baik". Hal ini menunjukkan bahwa LKPD dengan berorientasi HOTS yang dikembangkan memenuhi aspek kevalidan, kepraktisan dan membantu peserta didik dalam meningkatkan kemampuan berfikir tingkat tinggi sehingga layak digunakan dalam proses pembelajaran matematika.

Penelitian selanjutnya mengenai pengembangan LKPD ini dilakukan oleh Septian et al. (2019). Respon peserta didik terhadap penggunaan LKPD dalam pembelajaran matematika dengan berbasis pada Model Realistic Mathematics Education menghasilkan respon peserta didik sebanyak 93\% dengan kriteria sangat setuju menggunakan LKPD dalam pembelajaran matematika. Selanjutnya terdapat pengaruh dalam penggunaan LKPD matematika berbasis Model Realistic Mathematics Education terhadap prestasi belajar peserta didik. Hasil rata-rata nilai posttest di kelas ekperimen adalah 77,9 sedangkan di kelas kontrol adalah 68,7.

Selanjutnya terdapat penelitian penggunaan model pembelajaran problem based learning dalam kegiatan pembelajaran matematika. Penelitian yang dilakukan oleh (Indarwati, 2014) bertujuan untuk meningkatkan kemampuan pemecahan masalah operasi hitung bilangan pecahan melalui penerapan problem based learning. Berdasarkan hasil penelitian dan pembahasan tersebut, didapati bahwa melalui penerapan problem based learning dalam kegiatan pembelajaran matematika dapat meningkatkan kemampuan pemecahan masalah operasi hitung bilangan pecahan pada siswa kelas $\mathrm{V}$ SDN Mlowo Karangtalun 04 Kecamatan Pulokulon Kabupaten Grobogan. Kemampuan pemecahan masalah dengan penerapan problem based learning mengalami peningkatan dari siklus 1 sampai siklus 2, pada siklus 1 siswa yang tuntas KKM sebanyak 17 siswa dengan persentase $74 \%$ dari 23 siswa, dan pada siklus 2 terjadi peningkatan sebanyak 20 siswa dengan persentase $87 \%$ dari 23 siswa dengan KKM 65 dan indikator kinerja 85\%.

Penelitian terdahulu mengenai problem based learning juga dilakukan oleh Rahmadani \& Taufina (2020). Berdasarkan hasil penelitian dan pengembangan tersebut, didapati bahwa media pembelajaran Multimedia Interaktif pada pembelajaran Tematik Terpadu dengan Model PBL di Kelas V Sekolah Dasar dikategorikan "sangat valid". Hal ini dapat dilihat berdasarkan hasil validasi bahan ajar oleh validator ahli dan praktisi pendidikan yang telah dilaksanakan, baik pada RPP dan media interaktif yang dikembangkan. Multimedia Interaktif dikatakan praktis dilihat dari keterlaksanaan bahan ajar dan RPP oleh observer terhadap guru yang mengajar dengan kategori sangat praktis. Multimedia Interaktif dikatakan efektiv pada penelitian ini dilihat dari aktivitas siswa dan hasil belajar.

Berdasarkan penelitian terdahulu tersebut, peneliti ingin menggabungkan antara pengunaan LKPD dengan model pembelajaran problem based learning. Hasil dari penelitian dan pengembangan ini adalah sebuah produk lembar kerja peserta didik (LKPD) berbasis problem based learning. Penelitan dan pengembangan ini bertujuan untuk mengembangkan suatu produk pembelajaran yang tepat guna dan sesuai dengan kemampuan berfikir siswa kelas IV sekolah dasar. Produk yang dikembangkan merupakan bahan ajar cetak yang berisi lembaranlembaran aktivitas kerja peserta didik dengan berbasis problem based learning pada materi matematika segi banyak beraturan, segi banyak tidak beraturan, keliling dan luas persegi, persegi panjang dan segitiga. Lembar kerja peserta didik memerhatikan aspek pemecahan masalah sehingga langkah- 
Septiana Andeswari , Dudung Amir Sholeh, Linda Zakiyah

Pengembangan Lembar Kerja Peserta Didik (LKPD) Berbasis Problem Based Learning dalam Pembelajaran Matematika Kelas IV Sekolah Dasar

Prima Magistra: Jurnal Ilmiah Kependidikan Volume 3, Nomor 1, Januari 2022, hal 48-61

langkah dan pertanyaan-pertanyaan yang disajikan dapat mendorong peserta didik untuk mengembangkan kemampuan pemecahan masalahnnya.

Penelitian ini dilakukan atas dasar analisis kebutuhan yang telah dilaksanakan di SDN Randusongo 1, Ngawi. Berdasarkan hasil analisis kebutuhan tersebut, didapati bahwa dalam kegiatan pembelajaran matematika guru belum pernah menggunakan lembar kerja peserta didik, baik yang dikembangkan sendiri maupun yang telah tersedia. Dalam kegiatan pembelajaran, guru hanya menggunakan latihan-latihan soal yang terdapat didalam buku paket yang disediakan oleh sekolah. Pembelajaran masih cenderung satu arah dimana guru hanya menyampaikan materi kepada peserta didik. Belum digunakan suatu model pembelajaran yang inovatif yang dapat membantu peserta didik melatih pemecahan masalahnya. Sehingga dalam pemebelajaran matetika di kelas IV ini, khususnya dalam materi bangun datar, peserta didik hanya mengandalkan hafalan dan tidak mengerti makna dari rumus yang dihafalkannya.

Berdasarkan beberapa hal tersebut, peneliti mengembangakn suatu produk bahan ajar cetak berupa lembar kerja peserta didik yang berbasis kepada problem based learning dalam materi bangun datar untuk kelas IV sekolah dasar. Pelaknasaan penelitian ini menggunakan model pengembanganya Borg and Gall yang memiliki 10 tahapan yakni (1) penelitian dan pengumpulan informasi, (2) perencanaan, (3) pengembangan draft produk awal, (4) uji coba lapangan awal, (5) revisi hasil uji coba, (6) uji lapangan produk utama, (7) revisi produk, (8) uji coba lapangan skala luas, (9) revisi akhir produk, (10) diseminasi.

Kesepuluh langkah menurut Borg and Gall dalam penelitian dan pengembangan ini bukan prosedur yang harus diikuti keseluruhannya, melainkan peneliti dapat menyesuaikan dengan kebutuhannya. Pada penelitian dan pengembangan ini, peneliti melaksanakan langkah penelitian hanya sampai tahap kesembilan. Peneliti hanya menyelesaikan hingga tahap kesembilan dikarenakan keterbatasan waktu yang dimiliki peneliti dan juga peneliti tidak memiliki ruang lingkup yang besar untuk menyelesaikan hingga tahap kesepuluh.

Tahapan pertama dalam penelitian dan pengembangan ini adalah penelitian dan pengumpulan informasi. Pengumpulan informasi dilakukan peneliti untuk mengetahui kebutuhan sekolah dan peserta didik akan suatu pengembangan lembar kerja peserta didik berbasis problem based learning. Pengumpulan informasi di awal juga dilaksanakan untuk mengetahui profil peserta didik, merumuskan tujuan umum dan khusus dari pengembangan lembar kerja peserta didik ini, menyusun garis besar isi lembar kerja peserta didik, menentukan media, merencanakanpendukung pembelajaran dan mempertimbangkan bahan ajar yang sudah ada.

Garis besar isi dalam lembar kerja peserta didik matematika ini dirumuskan berdasarkan kompetensi dasar dan indikator materi bangun segibanyak beraturan, segi banyak tidak beraturan, luas dan kelilling bangun persegi, persegi panjang dan segitiga. Adapun kompetensi dasar pada materi ini yakni 1) Menganalisis sifat-sifat segibanyak beraturan dan segibanyak tidak beraturan, 2) Mengidentifikasi segibanyak beraturan dan segibanyak tidak beraturan, 3) Menjelaskan dan menentukan keliling dan luas persegi, persegi panjang, dan segitiga serta hubungan pangkat dua dengan akar pangkat dua dan 4) Menyelesaikan masalah berkaitan dengan keliling dan luas persegi, persegi panjang, dan segitiga termasuk melibatkan pangkat dua dengan akar pangkat dua.

Berdasarkan kompetensi dasar tersebut, maka dapat dirincikan garis besar isinya adalah sebagai berikut: 1) Segibanyak beraturan dan segibanyak tidak beraturan, 2) Kedua adalah mencari keliling dan luas bangun persegi, 3) Ketiga adalah mencari keliling dan luas bangun persegi panjang, 4) Keempat adalah mencari keliling dan luas bangun segitiga. Adapun, untuk lebih jelasnya garis besar isi dari produk penelitian dan pengembangan ini dapat dilihat dari bagan berikut: 
Septiana Andeswari , Dudung Amir Sholeh, Linda Zakiyah

Pengembangan Lembar Kerja Peserta Didik (LKPD) Berbasis Problem Based Learning dalam Pembelajaran Matematika Kelas IV Sekolah Dasar

Prima Magistra: Jurnal Ilmiah Kependidikan Volume 3, Nomor 1, Januari 2022, hal 48-61

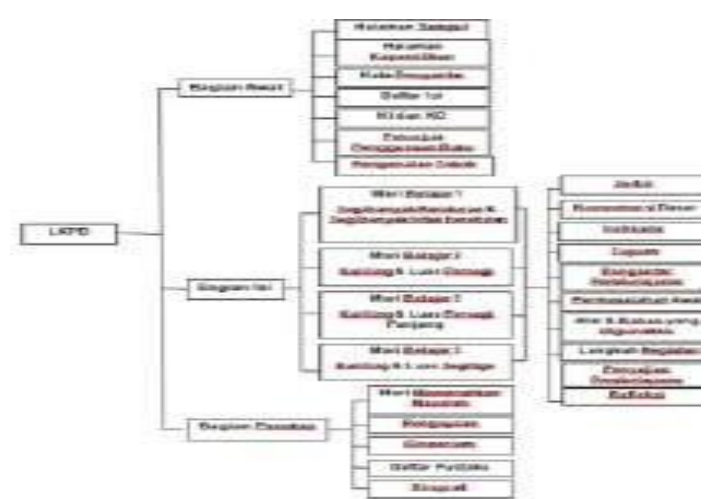

Gambar 2 : Garis besar isi produk yang dikembangkan

Dalam tahapan pengumpulan infornasi tersebut dapat diketahui bahwa terdapat kebutuhan untuk mengembangakan suatu produk bahan ajar, yakni pengembangan lembar kerja peserta didik berbasis pada problem based learning.

Tahapan selajutnya adalah persiapan atau perencanaan. Dalam tahapan persiapan perencanaan produk ini, mencakup beberapa tahapan, seperti mempertimbangkan sumber dan hambatan-hambatan dalam mengembangkan produk, mengurutkan ide atau gagasan penulisan, mengembangkan kegiatan-kegiatan dalam produk, menentukan gambar-gambar dan grafis dan menentukan peralatan yang dibutuhkan dalam mempersiapkan produk kedalam bentuk fisik.

Dalam tahapan perencanaan produk, peneliti mempertimbangkan hambatanhambatan yang terjadi dalam penelitian dan pengembangan lembar kerja peserta didik. Dalam proses mempersiapkan gambar ilustrasi pada produk ini, illustrator membutuhkan waktu kurang lebih selama dua minggi untuk menyelesaikan seluruh gambar yang terdapat pada produk. Tahap penulisan membutuhkan waktu kurang lebih satu bulan hingga produk siap untuk dicetak. Setelah itu, pada tahap uji ahli (expert review) peneliti mempertimbangkan keadaan dimana semua bekerja dari rumah sehingga untuk penilaian uji ahli memerlukan waktu yang sedikit lama. Selanjutnya, dalam tahap uji coba diperkirakan membutuhkan kesediaan peserta didik untuk melakukan zoom meeting untuk menguji produk yang dikembangkan.

Ide penulisan dalam pengembangan produk ini terbagi kedalam empat kegiatan pembelajaran. Kegiatan pembelajaran pertama berisi kegiatan-kegiatan yang dilakukan oleh peserta didik untuk dapat membedakan bangun segi banyak beraturan dan bangun segi banyak tidak beraturan. Kegiatan pembelajaran kedua adalah kegiatan yang dilakukan untuk menemukan bagaimana cara menghitung keliling dan luas bangun datar persegi. Kegiatan pembelajaran ketiga adalah kegiatan yang dilakukan untuk menemukan bagaimana cara menghitung keliling dan luas bangun datar persegi panjang. Kegiatan belajar keempat adalah kegiatan yang dilakukan untuk menemukan bagaimana cara menghitung keliling dan luas bangun datar segitiga.

Seluruh kegiatan dalam lembar kerja peserta didik dirancang untuk membaantu peserta didik melatih kemampuan pemecahan masalahnya. Kegiatan disajikan dengan pemberian masalah awal yang harus dianalisis oleh peserta didik lalu langkah-langkah kegiatan yang menarik yang membantu peserta didik untuk memecahkan masalah. Selanjutnya peserta didik akan diarahkan untuk mempresentasikan hasil temuan mereka, menyimpulkan kegiatan pembelajaran dan diakhir akan ada tes formatif yang bertujuan untuk mengembangkan lebih luas lagi pemahaman peserta didik akan materi yang telah dipelajarinya.

Lembar kerja peserta didik ini dikembangkan dengan memuat permasalahan, kegiatan-kegiatan dan langkah-langkah kerja yang dilakukan oleh peserta didik dalam setiap kegiatan belajarnya. Kegiatan-kegiatan teresebut antara lain yakni kegiatan yang mengarahkan peserta didik untuk menemukan konsep segi banyak beraturan, segi banyak tidak beraturan, luas dan keliling, kegiatan yang mengarahkan peserta didik untuk menemukan perbedaan yang berkaitan dengan segi banyak beraturan dan segi banyak tidak beraturan, dan kegiatan yang mengarahkan peserta didik untuk menyelesaikan masalah yang berkaitan dengan luas dan keliling.

Selama kegiatan pembelajaran yang tersaji dalam lembar kerja peserta didik, peserta didik dapat berkolaborasi dengan orang tua atau saudara lainnya dilingkungan rumah. Selain itu, peserta didik dapat 
Septiana Andeswari , Dudung Amir Sholeh, Linda Zakiyah

Pengembangan Lembar Kerja Peserta Didik (LKPD) Berbasis Problem Based Learning dalam Pembelajaran Matematika Kelas IV Sekolah Dasar

Prima Magistra: Jurnal Ilmiah Kependidikan Volume 3, Nomor 1, Januari 2022, hal 48-61

memberikan umpan balik dalam setiap kegiatan pembelajaran berupa kesimpulan dan hasil dari kegiatan pembelajaran. Peserta didik juga dapat menuliskan bagian mana yang belum mereka pahami dan pendapat mereka tentang pembelajaran tersebut di kolom yang disediakan dalam lembar kerja peserta didik.

Menentukan desain gambar dan grafis merupakan salah satu faktor penting yang harus dipersiapkan dalam pengembangan produk lembar kerja peserta didik ini. Gambar atau grafis berfungsi untuk membantu peserta didik dalam memahami maksud materi. Gambar atau grafis ini juga digunakan sebagai nilai tambah dalam penyajian lembar kerja peserta didik karena dapat menjadi daya tarik bagi penggunanya. Layout buku yang memiliki gambar-gambar dan warna yang menarik akan dapat membantu menarik minat

peserta didik untuk belajar.

Selain itu, gambar yang digunakan akan sangat membantu peserta didik dalam memahami maksud materi lebih dalam lagi. Setiap permasalahan yang tersaji dalam lembar kerja peserta didik ini menggunakan ilustrasi gambar sabagai penyambungnya. Hal ini seperti terlihat saat menampilkan ilutrasi bahan dan alat sehingga peserta didik tidak melakukan kekeliruan.

Langkah penelitian yang ketiga adalah penulisan draft awal produk. terdapat beberapa tahapan dalam persiapan penulisan produk ini, seperti tahapan penulisan dan penyuntingan yang dimulai dengan membuat draft produk, melengkapi draft dan kembali menyuntingnya, mengujicobakan produk kepada peserta didik dan melakukan revisi atau perbaikan pada produk.
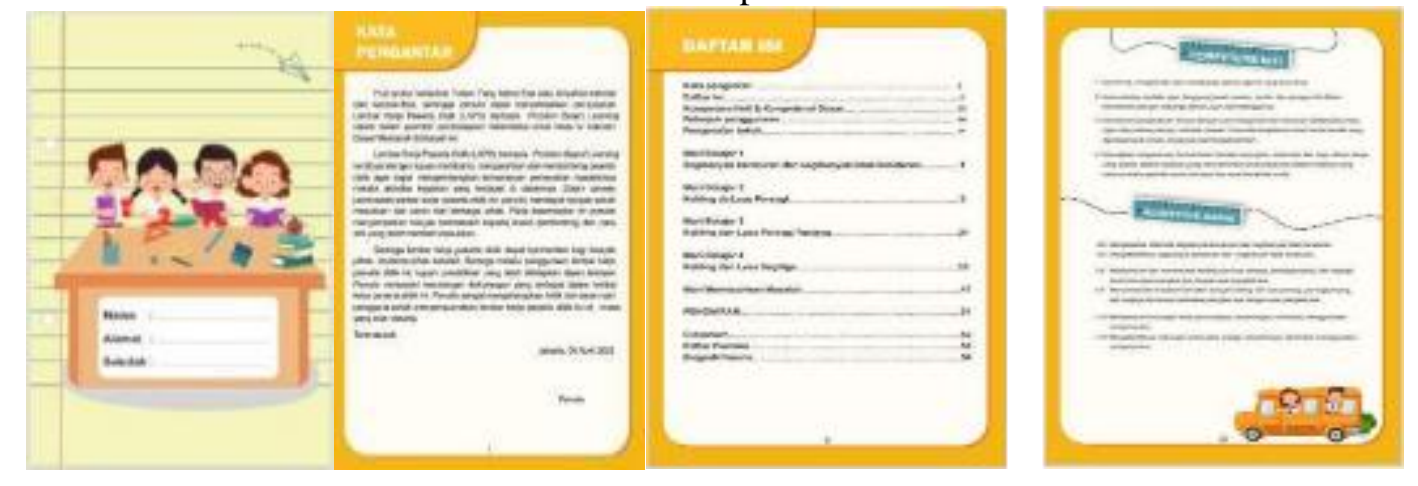

Gambar 3 : Draft awal produk

Tahapan selajutnya adalah Preliminary Field Testing (uji coba lapangan awal). Preliminary Field Testing dilakukan oleh peneliti dengan 5 orang peserta didik kelas IV SDN Randusongo 1 yang memiliki kemampuan berpikir berbeda sebagai responden. Kelima peserta didik tersebut melakukan penilaian terhadap produk lembar kerja peserta didik yang dikembangkan oleh peneliti menggunakan teknik wawancara dengan pertanyaan-pertanyaan yang telah disediakan oleh peneliti. Kegiatan wawancara ini terdiri dari 8 butir pertanyaan berdasarkan aspek penilaian Preliminary Field Testing. Butir pertanyaan ini diisi oleh peserta didik berdasarkan pendapatnya masing-masing berkaitan dengan produk yang dikembangkan peneliti. Uji coba dilaksanakan secara jarak jauh menggunakan bantuan aplikasi whatsApp dan zoom meeting.
Adapun beberapa aspek penilaian dalam tahap Preliminary Field Testing adalah sebagai berikut, (1) penyajian materi, (2) aspek problem based learning, (3) tampilan, (4) ukuran, dan (5) bahasa.

Tahapan selajutnya adala revisi produk berdasarkan Preliminary Field Testing atau uji coba lapangan awal. Berdasarkan penialain 5 orang peserta didik kelas IV SDN Randusongo 1 , terdapat beberapa perbaikan- perbaikan dalam tampilan maupun penyajian lembar kerja peserta didik. Revisi tersebut antara pengunaan warna latar yang kurang sesuai dan susunan kalimat yang terlalu sulit untuk dibaca.

Tahapan keenam adalah uji coba lapangan produk utama. Produk yang telah dikembangkan dan telah dilakukan revisi akan di uji cobakan kembali dalam tahap Main 
Septiana Andeswari , Dudung Amir Sholeh, Linda Zakiyah

Pengembangan Lembar Kerja Peserta Didik (LKPD) Berbasis Problem Based Learning dalam Pembelajaran Matematika Kelas IV Sekolah Dasar

Prima Magistra: Jurnal Ilmiah Kependidikan Volume 3, Nomor 1, Januari 2022, hal 48-61

Field Testing atau uji lapangan produk utama. Dalam penelitian ini, peneliti melibatkan tiga orang ahli (expert review), guru dan peserta didik kelas IV SDN Randusongo 1. Uji coba lapangan ini dilakukan dengan menyebarkan kuisioner kepada peserta didik dan melakukan wawancara kepada guru kelas IV SDN Randusongo 1, Ngawi.

Uji coba atau penilaian expert review ini dilakukan oleh tiga orang ahli yang akan melakukan validasi terhadap produk yang dikembangkan oleh peneliti. Adapun tiga orang ahli dalam tahapan ini yakni adalah ahli materi, ahli bahasa dan ahli media. Validasi produk ini dilakukan oleh para ahli (expert review) menggunakan kuesioner. Hasil validasi yang diberikan oleh ahli media, ahli materi dan ahli bahasa tersebut digunakan peneliti untuk memparbaiki atau menyempurnakan produk lembar kerja peserta didik yang sedang dikembangkan.

Ahli media memberikan penilaian terhadap lembar kerja peserta didik berbasis problem based learning sebesar $\mathbf{8 2 . 2 8 \%}$ dan perolehan skor tersebut produk lembar kerja peserta didik memiliki kriteria sangat layak, tidak perlu direvisi lagi untuk digunakan. Ahli media berpendapat bahwa lembar kerja peserta didik yang dikembangkan sudah sangat baik dengan penyajian yang menarik. Saran perbaikan oleh ahli media ini adalah penambahan logo, tata letak gambar yang semula lebih banyak terletak di kiri diubah menjadi lebih banyak terletak di kanan, penambahan foto penulis dalam biografi di akhir lembar kerja peserta didik dan perubahan nama-nama tokoh yang ada didalam lembar kerja peserta didik.
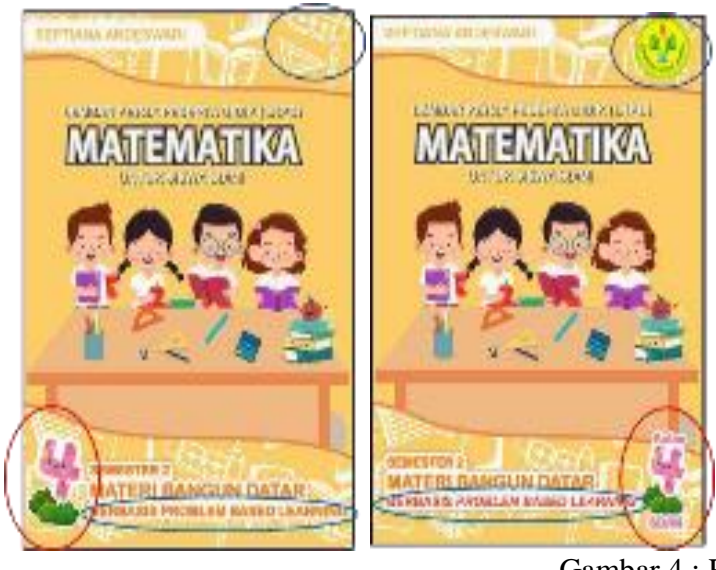

Gambar 4 : Revisi ahli media
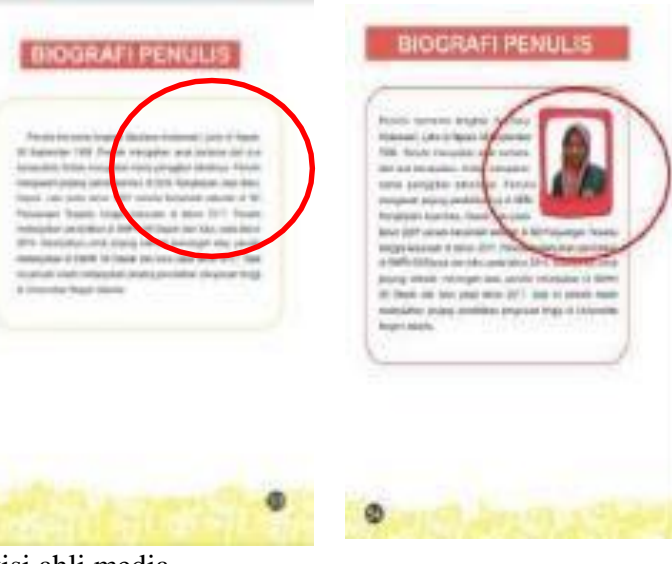

Ahli materi memberikan penilaian terhadap lembar kerja peserta didik berbasis problem based learning sebesar $\mathbf{9 0 . 4 7 \%}$ dan perolehan skor tersebut produk lembar kerja peserta didik memiliki kriteria sangat layak, tidak perlu direvisi lagi untuk digunakan. Ahli materi berpendapat bahwa lembar kerja peserta didik yang dikembangkan sudah sangat baik. Penyajian dan langkah-langkah problem based learning dapat terlihat dengan jelas dan membantu peserta didik dalam melatih kemampuan berfikirnya. Saran yang diberikan oleh ahli materi yakni perubahan dalam indikator pembelajaran yang lebih menyesuaikan kepada kompetensi dasra. Terdapat masukan juga oleh ahli materi yakni penambahan keterangan pada setiap petunjuk penggunaan. Penambahan keterangan bertujuan untuk memperjelas tahapan-tahapan problem based learning. Selain itu juga terdapat penambahan petunjuk penggunaan buku yakni "Ayo Sajikan" dan "Refleksi" yang sebelumnya tersirat berada didalam kegiatan pembelajar sekarang dituliskan dengan jelas. Begitu pula untuk didalam buku, selanjutnya "Ayo sajikan" dan "Refleksi" tertulis jelas dalam setiap kegiatan pembelajaran. 

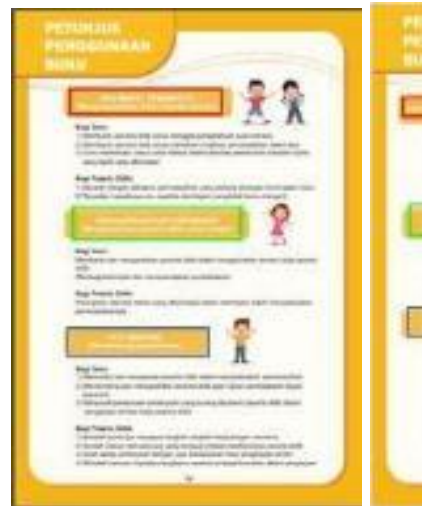
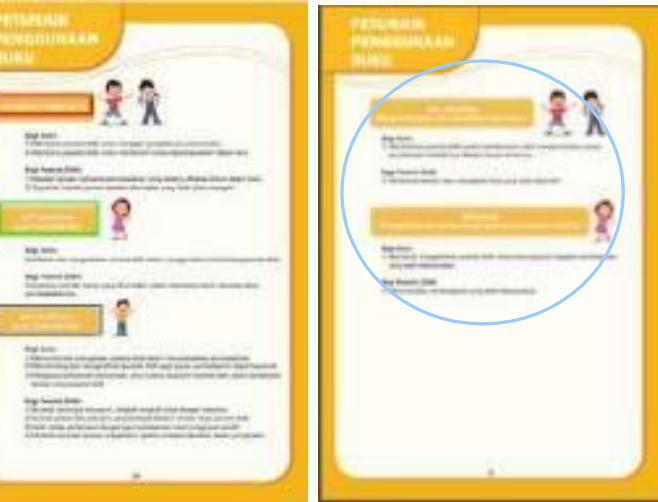

Gambar 5 : Revisi ahli materi
Ahli bahasa memberikan penilaian terhadap lembar kerja peserta didik berbasis problem based learning sebesar $\mathbf{7 3 . 3 \%}$ dan perolehan skor tersebut produk lembar kerja peserta didik memiliki kriteria sangat layak, tidak perlu direvisi lagi untuk digunakan. Saran dari ahli bahasa yakni perbaikan pada kata pertama-tama. Perbaikan dilakukan karena kata pertama-taman bukan merupakan kata baku dalam bahasa Indonesia. Penggantian kata dilakukan agar tidak terdapat kesalahpamahan bahasa baku Indonesia pada peserta didik.

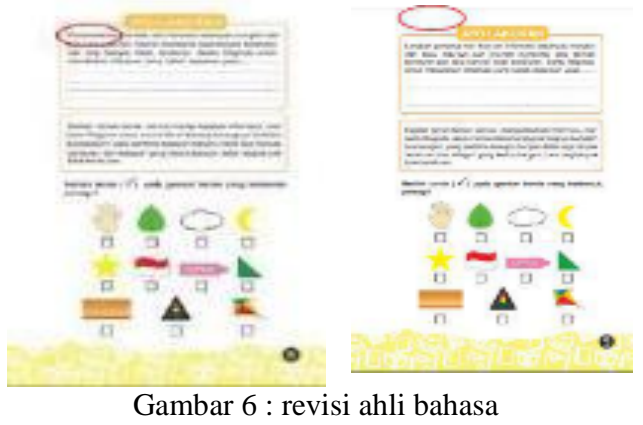

Berdasarkan uji ahli materi, ahli media dan ahli bahasa yang telah melakukan validasi terhadap produk lembar kerja peserta didik berbasis problem based learning pada materi geometri kelas IV sekolah dasar dapat dikatakan bahwa produk yang dikembangkan peneliti sangat baik dengan rata-rata keseluruhan 82.02\% dan hanya memerlukan sedikit perbaikan. Produk yang sudah melalui tahap perbaikan dari para ahli selanjutnya di uji cobakan kembali kepada peserta didik.

Selanjutnya, peneliti melakukan uji lapangan utama dalam pengembangan produk ini. Dalam penelitian ini, peneliti melibatkan guru dan peserta didik kelas IV SDN Randusongo 1. Uji coba lapangan ini dilakukan dengan menyebarkan kuisioner kepada peserta didik dan melakukan wawancara kepada guru kelas IV SDN Randusongo 1, Ngawi.

Penilaian produk LKPD dalam tahapan ini melibatkan 10 orang peserta didik kelas IV SDN Randusongo 1. Dalam tahapan ini peneliti tidak melibatkan peserta didik yang telah mengikuti uji coba Preliminary Field Testing. Uji coba lapangan dilakukan guna mengidentifikasi penggunaan lembar kerja peserta didik apabila digunakan pada kondisi yang mirip dengan sebenarnya. Hasil dari uji coba ini digunakan untuk mengetahui pendapat peserta didik akan produk yang dikembangkan.

Setelah pengisian kuisioner yang dilakukan oleh 10 orang peserta didik, peneliti melakukan wawancara dengan guru kelas IV SDN Randusongo 1. Wawancara dilakukan guna mengetahui pendapat guru mengenai produk yang dikembangkan, apakah ada kesulitan bagi guru dalam menggunakan produk yang dikembangkan dan bagaimana ketertarikan guru dalam menggunakan produk yang dikembangkan dalam kegiatan pembelajaran.

Dalam tahap Uji Lapangan Utama ini peneliti menggunakan instrumen kuesioner dengan peserta didik menjadi penilai (responden). Peserta didik mengisi instrument berupa kuesioner yang disebarkan melalui google form dengan pilihan jawaban "ya" dan "tidak". Untuk jawaban "ya" bernilai 1 dan untuk jawaban "tidak" bernilai 0 pada setiap indikatornya. Hasil data kuantitatif yang diperoleh dari hasil kuesioner diubah menjadi data kualitatif. 
Septiana Andeswari , Dudung Amir Sholeh, Linda Zakiyah

Pengembangan Lembar Kerja Peserta Didik (LKPD) Berbasis Problem Based Learning dalam Pembelajaran Matematika Kelas IV Sekolah Dasar

Prima Magistra: Jurnal Ilmiah Kependidikan Volume 3, Nomor 1, Januari 2022, hal 48-61

Berdasarkan hasil Preliminary Field Testing, diperoleh data hasil rekapitulasi sebagai berikut:

\begin{tabular}{cccc}
\hline $\begin{array}{c}\text { No. } \\
\text { Respon } \\
\text { den }\end{array}$ & $\begin{array}{c}\text { Jumlah } \\
\text { skor }\end{array}$ & $\boldsymbol{\%}$ \\
\hline 1. & CES & 29 & 100 \\
2. & DWS & 28 & 96.55 \\
3. & ENA & 29 & 100 \\
4. & ENA & 27 & 93.10 \\
5. & LDA & 28 & 96.55 \\
6. & MMM & 26 & 89.66 \\
7. & RMA & 28 & 96.55 \\
8. & RW & 28 & 96.55 \\
9. & TM & 27 & 93.10 \\
10. & WAP & 26 & 89.66 \\
\hline & Jumlah & $\mathbf{2 7 6}$ & $\mathbf{9 5 . 1 7}$ \\
& & & $\mathbf{\%}$ \\
\hline
\end{tabular}

\section{SIMPULAN DAN SARAN}

Berdasarkan Hasil kuisioner peserta didik kelas IV SDN Randusongo 1 yakni hasil Uji Coba Lapangan Utama diperoleh hasil dari peserta didik bahwa lembar kerja peserta didik mendapatkan nilai $\mathbf{9 5 . 1 7 \%}$ yang berarti produk dapat dikatakan sangat layak dan tidak perlu perbaikan. Berdasarkan hasil wawancara dengan guru kelas IV sekolah dapat disimpulkan bahwa guru tidak mengalami kesulitan dalam menggunakan produk dan merasa tertarik menggunakan produk yang dikembangkan. Berdasarkan Hasil kuisioner peserta didik dan hasil wawancara dengan guru kelas IV SDN Randusongo 1 tersebut dapat disimpulkan bahwa lembar kerja peserta didik sangat baik dan layak digunakan dalam kegiatan pembelajaran matematika dan tidak memerlukan perbaikan lagi. Berdasarkan evalusi penilaian dari hasil uji validasi yang telah dilakukan baik dari expert review, preliminary field testing, dan main field testing dapat dikatakan bahwa produk lembar kerja peserta didik berbasis problem based learning dalam pembelajaran matematika siswa kelas IV sekolah dasar merupakan produk yang valid. Adapun produk ini juga dapat digunakan sebagai sumber belajar tambahan bagi peserta didik maupun guru pada kegiatan belajar Matematika materi segibanyak beraturan, segibanyak tidak beraturan, keliling dan luas persegi, persegi panjang dan segitiga di kelas IV Sekolah Dasar. Produk lembar kerja peserta didik ini juga dapat dijadikan sumber belajar peserta didik dalam kegiatan belajar mandiri maupun kelompok.

Berdasarkan penelitian dan pengembangan produk lembar kerja peserta didik berbasis problem based learning didapati beberapa saran sebagai berikut, 1) kepada guru kelas IV, produk lembar kerja peserta didik berbasis problem based learning materi segibanyak beraturan, segibanyak tidak beraturan, luas dan keliling persegi, persegi panjang dan segitiga ini dapat digunakan oleh guru sebagai sumber belajar tambahan untuk melatih kemampuan pemecahan masalah peserta didik dan menambah minat belajar peserta didik pada materi tersebut, 2) kepada kepala sekolah, dapat menambah koleksi perangkat pembelajaran kurikulum 2013 dan menambah inovasi ragam pembelajaran matematika di sekolah khususnya pada pembelajaran matematika materi segibanyak beraturan, segibanyak tidak beraturan, luas dan keliling persegi, persegi panjang dan segitiga ini, dan 3) kepada peneliti selanjutnya, penelitian dan pengembangan dapat digunakan sebagai referensi penelitian agar dapat mengembangkan produk lembar kerja peserta didik serupa dengan materi dan tema belajar yang lebih luas dan menarik lagi untuk dikembangkan.

\section{DAFTAR PUSTAKA}

Andrayani, N. N. (2015). Pengaruh Strategi Problem Solving menurut Wankat dan Oreovicz terhadap Kemampuan Pemahaman Konsep Matematis Dan Self-Regulaed Learning Siswa. UPI Eduhumaniora: Jurnal Pendidikan Dasar, $\quad 7(2), \quad$ 173-185. https://doi.org/http://dx.doi.org/10.1750 9/eh.v7i2.2708

Caswita, C., \& Bharata, H. (2019). Pengembangan Lembar Kerja Peserta Didik Berbasis Problem Based Learning untuk Meningkatkan Kemampuan Penalaran Matematika. Desimal: Jurnal Matematika, 2(2), 141-146. http://ejournal.radenintan.ac.id/index.ph $\mathrm{p} / \mathrm{desimal} / \mathrm{index}$

Fathurohman, I., \& Ulya, H. (2021). Analisis Keterampilan Membaca Permulaan dan Berhitung pada Siswa Sekolah 
Septiana Andeswari , Dudung Amir Sholeh, Linda Zakiyah

Pengembangan Lembar Kerja Peserta Didik (LKPD) Berbasis Problem Based Learning dalam Pembelajaran Matematika Kelas IV Sekolah Dasar

Prima Magistra: Jurnal Ilmiah Kependidikan Volume 3, Nomor 1, Januari 2022, hal 48-61

Dasar. WASIS: Jurnal Ilmiah Pendidikan, 2(2), 79-87. https://doi.org/10.24176/wasis.v2i2.616 3

Fauzi, I., \& Arisetyawan, A. (2020). Analisis Kesulitan Belajar Siswa pada Materi Geometri Di Sekolah Dasar. Kreano, Jurnal Matematika Kreatif-Inovatif, 11(1), 27-35. https://doi.org/10.15294/kreano.v11i1.2 0726

Fitrianti, M. (2021). Peningkatan Hasil Belajar Dalam Pembelajaran Matematika Melalui Kooperatif Tipe Number Head Together (NHT) Pada Siswa Sekolah Dasar. Tadulako Educational Research Journal, $\quad$ 1(1), 32-40. https://jurnal.fkip.untad.ac.id/index.php /terj/article/view/874

Hanafi. (2017). Konsep Penelitian $R \& D$ Dalam Bidang Pendidikan. Saintifika Islamica: Jurnal Kajian Keislaman, 4(2), 129-150. http://jurnal.uinbanten.ac.id/index.php/s aintifikaislamica/article/view/1204

Handayani, N. (2021). Model Pembelajaran Kooperatif Tipe Snowball Throwing Tingkatkan Hasil Belajar Pecahan pada Siswa Kelas V SDN Urangagung Sidoarjo. Jurnal Pendidikan Tambusai, 5(1), 615-619. https://jptam.org/index.php/jptam/articl e/view/993

Indarwati， D. dkk. (2014). Peningkatan Kemampuan Pemecahan Masalah Matematika Melalui Penerapan Problem Based Learning Untuk Siswa Kelas V SD. Jurnal Satya Widya, 30(1), 17-27. https://ejournal.uksw.edu/satyawidya/ar ticle/view/107

Komalasari, K. (2017). Pembelajaran Kontekstual. Bandung: PT Refika Aditama. Google Scholar

Lestari, I. (2015). Pengaruh waktu belajar dan minat belajar terhadap hasil belajar matematika. Formatif: Jurnal Ilmiah Pendidikan MIPA, 3(2). http://dx.doi.org/10.30998/formatif.v3i 2.118

Mala, N., Pamungkas, A. S., \& Alamsyah, T. P. (2020). Pengembangan Lembar Kerja Peserta Didik Matematika Berorientasi Higher Order Thinking Skills Di Sekolah Dasar. SJME (Supremum Journal of Mathematics Education), 4(2), 106-123. https://journal.unsika.ac.id/index.php/su premum/article/view/3406

Melindawati, S. (2016). Pengembangan Bahan Ajar Tematik Terpadu dengan Model Problem Based Learning di Kelas IV Sekolah Dasar. ESJ: Elementary School Journal PGSD FIP UNIMED, 5(1), 112.

https://jurnal.unimed.ac.id/2012/index.p hp/elementary/article/view/3974

OECD. (2014). PISA 2012 Results in Focus: What 15-year-olds know and what they can do with what they know. 1-42. https://www.voced.edu.au/content/ngv: 59795

Perdana, R., \& Suswandari, M. (2021). Literasi numerasi dalam pembelajaran tematik siswa kelas atas sekolah dasar. Absis: Mathematics Education Journal, 3(1), 9-15.

https://doi.org/10.32585/absis.v3i1.138 5

Pradita, N. E., \& Wangid, M. N. (2017). Pengembangan LKPD TematikIntegratif Berbasis Karakter pada Peserta Didik Sekolah Dasar. Jurnal Pendidikan Karakter UNY, 7(1), 56-70. https://journal.uny.ac.id/index.php/jpka/ article/view/15500

Rahmadani, R., \& Taufina, T. (2020). Pengembangan Multimedia Interaktif Berbasis Model Problem Based Learning (PBL) Bagi Siswa Sekolah Dasar. Jurnal Basicedu, 4(4), 938-946. https://doi.org/10.31004/basicedu.v4i4. 465

Septian, R., Irianto, S., \& Andriani, A. (2019). Pengembangan Lembar Kerja Peserta Didik (LKPD) Matematika Berbasis Model Realistic Mathematics 
Septiana Andeswari , Dudung Amir Sholeh, Linda Zakiyah

Pengembangan Lembar Kerja Peserta Didik (LKPD) Berbasis Problem Based Learning dalam Pembelajaran Matematika Kelas IV Sekolah Dasar

Prima Magistra: Jurnal Ilmiah Kependidikan Volume 3, Nomor 1, Januari 2022, hal 48-61

Education. Jurnal Educatio FKIP UNMA, 5(1), 59-67. https://ejournal.unma.ac.id/index.php/e ducatio/article/view/56

Sukmadinata, N.S. (2011). Metode Penelitian Pendidikan. Bandung: Remaja Rosadakarya. Google Scholar

Suprihatiningrum, J. (2017). Strategi Pembelajaran Teori dan Aplikasi. Jogjakarta: AR-RUZZ MEDIA. Google Scholar

Suputra, K. Y., Sujana, I. W., \& Darmawati, I. G. A. P. S. (2021). Penerapan Model
Problem Based Learning Berbantuan GeoGebra Meningkatkan Hasil Belajar Matematika. Journal of Education Action Research, 5(3), 423431. http://dx.doi.org/10.23887/jear.v5i 3.36898

Suryadi, D. (2010). Menciptakan proses belajar aktif: Kajian dari sudut pandang teori belajar dan teori didaktik. Bandung: Universitas Pendidikan Indonesia. Google Scholar 